\title{
INALIENABILITY AND THE THEORY OF PROPERTY RIGHTS
}

\section{Susan Rose-Ackerman*}

Inalienability is the stepchild of law and economics. Too often, economists note the existence of restrictions on transferability, ownership, and use, only to dismiss them as obviously inefficient constraints on market trades. Even Guido Calabresi and Douglas Melamed, who give inalienability explicit status in their theory of entitlements, treat it as an analytic stepchild to be justified by appeals to paternalism and moralism. ${ }^{1}$

On inspection, however, inalienability turns out to be a very complex concept, and one whose legitimate uses can be clarified through economic analysis combined with a sensitivity to noneconomic ideasmost notably ideals of citizenship and distributive justice. Inalienability can be defined as any restriction on the transferability, ownership, or use of an entitlement. So defined, inalienability is pervasive in modern, developed societies, in developing nations, and in the historical past. The variety and ubiquity of these restrictions suggest that a fuller analysis would help us better understand the role of private property in economic and social life. This Article begins such an analysis by first categorizing the possible types of restrictions, and then developing rationales that may justify some of these constraints on private ownership.

To do this, we must take a broader view of the role of legal entitlements than is expressed in most work on property rights in law and economics. Much of the existing literature emphasizes the way that efficient entitlement rules are affected by the technical characteristics of products and the costs of externality control. ${ }^{2}$ Fish, pasture land, for-

* Professor of Law and Political Economy, Columbia University. B.A. 1964, Wellesley College; Ph.D. 1970, Yale University. Research for this paper was partially supported by Columbia University's Center for Law and Economic Studies, the International Institute for Applied Systems Analysis, and Yale Unversity's Program on Nonprofit Organizations. Helpful comments were received from Bruce Ackerman, Guido Calabresi, Merritt Fox, Alvin Klevorick, Jerry Mashaw, Daniel Rubinfeld, Matthew Spitzer, Christopher Stone, and seminar participants at Stanford, University of Southern California, Yale, the 1983 annual meeting of the American Economic Association, and at Columbia Law School's Conference on New Directions in Law and Economics. Walter de la Cruz, Katherine Gorove and Tracey Thompson provided helpful research assistance.

1. Calabresi \& Melamed, Property Rules, Liability Rules, and Inalienability: One View of the Cathedral, 85 Harv. L. Rev. 1089 (1972).

2. For many of the basic articles, see Economic Foundations of Property Law (B. Ackerman ed. 1975); The Economics of Legal Relationships: Readings in the Theory of Property Rights (H. Manne ed. 1975); see also Demsetz, Toward a Theory of Property Rights, 57 Am. Econ. Rev. (Papers and Proceedings) 347 (1967) (reviewing literature); Furubotn \& Pejovich, Property Rights and Economic Theory: A Survey of Recent Liter- 
ests, oil pools, and minerals on the ocean bottom are only a few of the resources that have been subject to a property rights analysis. ${ }^{3}$ The research focuses rather narrowly on the efficiencies of private ownership systems that require people to take account of all the costs of resource use. Most of this work, moreover, has been excessively confident in the workings of the private market once property rights are firmly established and therefore views restraints on alienation with a great deal of skepticism. ${ }^{4}$

In contrast, Calabresi and Melamed believe that inalienability rules can sometimes be justified, but they do not attempt a full analysis of the rationales for restrictions on transferability, ownership, and use. ${ }^{5}$ Their work emphasizes instead the distinction between property rules and liability rules. Under a property rule, property can be sold, donated, or discarded, but only if the owner is willing to give up the entitlement and the recipient is willing to accept it. Under a liability rule, others may take your entitlement by, for example, destroying it in an accident, but they must then compensate you at a rate determined by a governmental body. Because Calabresi and Melamed's treatment of inalienability is colored by this emphasis on quid pro quo transfers, they discuss only one kind of inalienability-where ownership is legal but sales are not permitted-and they fail to discuss the economic rationales for even this form of restriction.

In the present paper I propose a broader based approach that seeks both to identify the range of possible restrictions and to develop normative rationales for some of these restrictions. Because my basic point of view is informed by economic theory, I start with the supposition that unencumbered market trades are desirable unless we can locate a valid reason for their restriction. I reject the idea that market trades are inherently coercive. Nevertheless, some forms of inalienability do have valid public policy justifications in a democratic market society. Three broad rationales are central to my argument. First, economic efficiency itself may require restrictions on property. This rationale goes beyond the familiar problems of externality control to include imperfect information, "prisoner's dilemmas," free rider problems, and the cost of administering alternative policies. Second,

ature, $10 \mathrm{~J}$. Econ. Literature 1137 (1972) (reviewing literature); North, Structure and Performance: The Task of Economic History, 16 J. Econ. Literature 963 (1978) (reviewing literature).

3. See, e.g., Anderson \& Hill, The Evolution of Property Rights: A Study of the American West, 18 J. L. \& Econ. 163 (1975); Gordon, The Economic Theory of a Common-Property Resource: The Fishery, 62 J. Pol. Econ. 124 (1954); Hardin, The Tragedy of the Commons, 162 Sci. 1243 (1968); Sweeney, Tollison \& Willett, Market Failure, The Common-Pool Problem, and Ocean Resource Exploitation, 17 J.L. \& Econ. 179 (1974).

4. See, e.g., Bureaucracy vs. Environment: The Environmental Costs of Bureaucratic Governance (J. Baden \& R. Stroup eds. 1981).

5. See Calabresi \& Melamed, supra note 1, at 1111-15. 
certain specialized distributive goals can only be achieved through some kind of inalienability rule. A general program of taxes and transfers may be inadequate. Third, unfettered market processes may be incompatible with the responsible functioning of a democratic state.

I begin in Part I by classifying entitlement rules by ownership, use, and transferability. My framework is less complex than the heterogeneity of the legal world, but more complex than previous attempts, such as Calabresi and Melamed's. 1 draw examples both from current controversies-including the sale of blood, military conscription, the preservation of historic buildings, and the protection of endangered species-and from such historical examples as the Homesteading Acts and the Civil War draft. My hope is that the taxonomy I propose will help scholars recognize similarities and salient differences between the broad diversity of entitlement restrictions currently in force. My framework should not be read, however, as an attempt to justify the entire range of existing constraints on property rights. Many of these have their roots in paternalistic attempts to impose moral values on others or in efforts by interest groups to obtain monopoly power.

In Part II, I develop efficiency and equity rationales for some existing restrictions and point out the analytic similarities between such disparate things as blood and used cars, or babies and lake trout. I demonstrate that inalienability rules can be second-best responses to various kinds of market failures and point out both how some restrictions on property rights serve redistributive goals and how other restrictions may impose unfair costs. Finally, I show in Part III how each of four distinct concepts of citizenship resolves the tension between efficiency and egalitarian values.

\section{A TAXonomy of Entitlements}

In examining the rationales for legal restrictions on entitlements, one must avoid being overwhelmed by the multitude of individual cases. To keep the analysis manageable, therefore, I will concentrate, in turn, on each of three dimensions of the problem: (1) who may hold the entitlement; (2) what actions the entitlement holder is required to perform to maintain title, and what actions are forbidden; and (3) what kinds of transfers are permitted. After outlining the important possibilities, I select a few of the most representative and interesting cases to discuss in more detail in the body of the paper.

\section{A. Restrictions on Ownership, Use and Transferability}

I begin first with the question of who may hold the entitlement. Legal rules may permit: (a) anyone, (b) only some specified groups, (c) everyone simultaneously, or (d) no one, to hold title. Cases (c) and (d) cover goods that cannot be privately owned, either because the state has declared them common property, so that exclusion of others is forbidden (navigable waters), or because they are illegal (heroin, liquor 
under Prohibition). In case (b), the state determines who may hold the entitlement. The class of qualified owners may include only those with some demographic characteristic such as old age or female sex, or it may be limited on the basis of some selection procedure such as an examination or a lottery.

Second, entitlement holders may face restrictions on the use of their property that are designed to produce some benefit or prevent some undesirable activity. We must distinguish between activities that are permitted, required, or forbidden. Since required activities are a subset of all permitted activities, the possible legal relationships between these distinctions are as follows:

\section{TABLE 1}

RESTRICTIONS ON USE

$\begin{array}{lccc}\text { Nothing is } & \begin{array}{c}\text { All Permitted } \\ \text { Activities are } \\ \text { Also Required }\end{array} & \begin{array}{c}\text { Some Permitted } \\ \text { Activities are } \\ \text { Also Required }\end{array} \\ \begin{array}{l}\text { Nothing is } \\ \text { Permitted }\end{array} & 1 & - & - \\ \begin{array}{c}\text { Nothing is } \\ \text { Forbidden }\end{array} & 2 & - & 3 \\ \begin{array}{l}\text { Some } \\ \text { Activities }\end{array} & & 5 & \\ \text { are } \\ \begin{array}{l}\text { Permitted } \\ \text { and } \\ \begin{array}{l}\text { Others are } \\ \text { Forbidden }\end{array}\end{array} & 4 & 5 & \\ \text { Case } & & & \end{array}$

Case (1) is one extreme: nothing can be done with the entitlement. In fact, in such a situation it seems odd to speak of entitlements at all. Case (2) is the opposite extreme: everything is permitted and nothing is required. ${ }^{6}$ Case (3) is somewhat more restrictive: everything is permitted so long as some required activities are carried out (e.g., a historic building preservation law). Under (4), some activities are forbidden but nothing is required (e.g., a zoning law). In (5), those who wish to retain title are required to perform certain activities, which are also the only activities permitted (e.g., a homestead law). In (6), a proper subset of the permitted activities is also required while other activities are forbidden (e.g., a zoning law in a community that also regulates historic buildings).

Third, consider the transferability and disposal of entitlements. Since regulation of the external costs imposed by the free disposal of

6. It would be logically possible to consider the middle box in Table 1 but not very realistic. Under such a rule, everything that can possibly be done with an entitlement is legally required. 
waste has been relatively well analyzed by others, ${ }^{7}$ I shall not emphasize it here. Instead, I concentrate on the difference between sales and gifts. Table 2 summarizes the four possibilities:

TABLE 2

RESTRICTIONS ON TRANSFERABILITY

\begin{tabular}{l|c|c} 
& Gifts Permitted & Gifts Forbidden \\
\hline Sales Permitted & pure property & modified property \\
& A & B \\
\hline Sales Forbidden & modified inalienability & pure inalienability \\
C & D
\end{tabular}

Under case (A), a pure property rule, all voluntary transfers are permitted. Under case (B), a modified property rule, only sales, generally at market prices, are permitted. Case $(C)$ is called modified inalienability because sales are outlawed while gifts are permitted. Case (D) represents pure inalienability.

\section{B. A Synthesis}

Putting together the three dimensions along which entitlements can vary yields almost one hundred cases. Since this Article deals with the control of private property, however, I will consider neither goods that cannot be used or legally possessed nor pure public goods. Of the forty cases that remain, the nine I examine can be divided into two general categories: those that affect the allocation and use of market goods and services and those that reflect alternative concepts of citizenship.

Within the market goods and services category, I begin by considering two cases that restrict transferability. Under the concept of modified inalienability, sales are forbidden, but gifts are permitted and may even be encouraged by state policy. Modified inalienability rules appear in such diverse contexts as the transplantation of body parts, the adoption of babies, and the preservation of endangered species. The converse of a modified inalienability rule is modified property. Under this rule, gifts are forbidden but sales at "fair" market prices are permitted. This rule generally does not apply to particular kinds of property but rather to particular situations. For example, an insolvent person or firm cannot give away valuable assets.

Three other cases involve limits on ownership and use. Thus, pure property with ownership restrictions limits the entitlement holders to individuals with particular attributes. They must be, for example, licensed physicians, persons who are over eighteen or over sixty-five, residents of Guilford, Connecticut, or persons approved by the board of directors. Transferability and use, however, are not restricted: the entitle-

7. See, e.g., Calabresi \& Melamed, supra note 1. 
ment can be sold or given to anyone else who also qualifies for ownership, and can be used without coercive conditions. Two simple cases involve restrictions on use: under required use, nothing is forbidden, but some uses are required, while under limited use, nothing is required, but some things are forbidden. Thus historical preservation laws require the preservation of certain buildings while zoning laws may forbid apartment buildings or commercial development on some pieces of land.

Finally, under systems of coerced use, all permitted activities are required and all other uses are forbidden. When such requirements are imposed on property owners, it is important to know whether the right is transferable or whether severe restrictions are imposed on an owner's right to dispose of his property. Under the former, called pure property with coercive use, a mineral lease, for example, may be sold or given away but will be lost if no mining is carried out. Under the latter rule, which I label conditional coercion, requirements are imposed on qualified entitlement holders, but people may waive these reponsibilities if they are willing to waive the entitlement as well. This kind of rule is more complex and restrictive than one that permits sales. The American homesteading laws, for example, gave land to families on the condition that they farm it for a fixed number of years. In a quite different context, many of today's goverument transfer programs for the needy are conditionally coercive.

Restraints on alienation are also imposed when people perform their responsibilities as citizens. Thus, the final group of categories embodies alternative concepts of citizenship. The categories are alienable rights-analogous to pure property rules with limits on ownership-inalienable rights, alienable duties-equivalent to coerced useand inalienable duties. These concepts can be understood by considering their different implications for voting rights, military service, and jury duty. Alienable rights can be sold or transferred to others and need not be exercised to be retained. Under this concept, the state has a volunteer army and permits the sale or donation of votes. Inalienable rights also need not be exercised, but the right cannot be sold or given away and some uses may be forbidden. Once a person is found qualified, however, there are no actions that must be taken in order to maintain the right. In the United States voting is an inalienable right, and some government social benefits also fall in this category. Alienable duties are activities required of a subset of the population that can be transferred to other persons willing to perform them. For example, during the Civil War, persons drafted into the army were permitted to buy substitutes. Finally, inalienable duties cannot legally be transferred through sales, gifts, or disposal. A military draft with no buy-out possibilities and jury duty are familiar examples.

To help keep these categories in mind as I proceed, Table 3 lists each type to be considered along with some important examples. The 
numbers and upper case letters in parentheses refer to the labels in Tables 1 and 2, respectively, and the lower case letters refer to alternative restrictions on ownership.

\section{TABLE 3}

\section{Entitlement Categories}

1) Inalienable Duties (5.D.b.)

2) Inalienable Rights (4.D.b.)

3) Conditional Coercion (5.C.b.)

4) Modified Inalienability (2.C.a.)

5) Modified Property (2.B.a.)

6) Pure property with ownership restrictions (alienable rights) (2.A.b.)

7) Pure property with required use (3.A.a.)

8) Pure property with limited use (4.A.a.)

9) Pure property with coercive use (alienable duties) (5.A.a.)

\section{Examples}

Army draft notices; jury duty; votes in Australia Votes in political contests in the United States Homesteads; benefits under some government transfer programs

Kidneys; hearts; wild game; babies

Prohibitions against gifts prior to declaration of bankruptcy

\section{Liquor; taxis in New York}

City; volunteer army

Historical preservation laws

Automobiles; land use zoning

Natural resource rights that must be used or lost; army draft in the United States Civil War

\section{EfFiciency aND EQuity Rationales}

\section{A. Overview of the Argument}

The objectives of this Article are primarily normative. I do not attempt to explain why any particular legal restriction was enacted into law. Instead, I ask whether plausible justifications can be given for some frequently observed legal patterns. This Part concentrates on three broad normative claims. First, the existence of transaction costs will frequently make a simple system of property-liability rules inefficient, ${ }^{8}$ so that more restrictive regulations such as inalienability rules may have merit. Second, distributive goals cannot always be achieved by simple lump sum transfers but may require more intrusive policies. Third, even when inalienability rules are justified on efficiency grounds,

8. See Coase, The Problem of Social Cost, 3 J.L. \& Econ. 1 (1960) (arguing that in the absence of transaction costs any clear cut allocation of property rights will be efficient); see also Cooter, The Cost of Coase, $11 \mathrm{~J}$. Legal Stud. 1 (1982) (exploring the implications of the proposition). 
compensation may be required to avoid imposing concentrated costs on particular individuals or groups.

The efficiency rationales for inalienability rules are second-best responses to market failures that arise because of externalities, imperfections in information, or difficulties of coordination. The straightforward responses of internalizing the externality through fees or taxes, of subsidizing the provision of information, and of facilitating joint action may, for one reason or another, be costly. In such cases, the alternative of restricting market trades becomes a realistic possibility. Instead of correcting the market failure through policies that rely on price incentives and market processes, inalienability rules address the difficulty with a set of prohibited or required actions that make market incentives less, rather than more, important. I consider each of the three types of market failure in turn.

Externalities figure prominently in discussions of market failure and provide the most commonly recoguized rationale for inalienability rules. Production and consumption externalities occur when the profits of firms or the satisfaction levels of individuals are affected by transactions in which they are not directly involved. These third parties would be willing to pay to obtain the benefits or to avoid the harms imposed on them, but because they are not part of the transaction, benefits are too low and costs are too high. For example, in the absence of regulation, a factory may create water pollution as part of its production process because it need not account for the harm caused by pollution. Economists generally seek to control externalities by creating market-like incentives through tax and subsidy schemes that encourage firms and individuals to respond to marginal shifts in costs and benefits. ${ }^{9}$ Economic analysts have also recognized that other alternatives that involve the definition or rearrangement of property rights may be equally satisfactory. Thus, externality problems may be solved by "internalizing" them or by providing "separate facilities" solutions. Under the former, a single individual is given title to both the property causing the externality and the property affected by it. So long as this does not create monopoly power, the new owner will have an incentive to behave efficiently. ${ }^{10}$ Under the latter, property relations are rearranged so that externality producers are separated from those who would suffer from the externality. ${ }^{11}$

Unfortunately, optimality may be difficult to achieve in a world

9. Any standard text in microeconomics or public finance discusses the public pricing of externalities. See, e.g., R. Musgrave \& P. Musgrave, Public Finance in Theory and Practice 692-715 (2d ed. 1976). For applications to environmental pollution, see Economics of the Environment (R. Dorfman \&c N. Dorfman 2d ed. 1977); A. Freeman, R. Haveman \& A. Kneese, The Economics of Environmental Policy (1973). pools).

10. See, e.g., Sweeney, Tollison \& Willett, supra note 3, at 186-88 (analyzing oil

11. See E. Mishan, The Costs of Economic Growth 80-99 (1967). 
with high transaction costs. Even a tort law system that places liability on the person who can most efficiently reduce the harm ${ }^{12}$ may not be effective in all situations, and taxes and subsidies may be difficult to implement because of political opposition or inadequate information. ${ }^{13}$ In the second-best world faced by regulators, there will be room for direct regulation of behavior. For example, suppose there is a strong statistical relationship between some characteristic of the user of a product and an external cost. Ex post, however, causation may be diffcult to establish in particular cases. Moreover, even if causation can be established, the individuals may not be wealthy enough to pay the claims against them. If a large portion of the class of individuals is involved, then the most effective way of reducing external costs may be to prevent the entire group (e.g., blind people and children) from using the product (e.g., driving an automobile). Similarly, other types of externalities can be prevented by regulating the use of a product. Speed limits and traffic siguals control driving over and above tort law rules that penalize negligent behavior.

Markets also frequently work poorly because information is imperfect and asymmetrical. This kind of market failure provides a second, and less widely recognized, rationale for inalienability rules in particular contexts. First, consider information asymmetries. If buyers are unaware of product defects, then high quality sellers cannot command higher prices than low quality sellers, and there may be a general deterioration in quality. A second information problem arises when two products look alike but one can be legally possessed while the other cannot. For example, laws protecting rare birds prohibit the taking of specimens after a set date but permit possession of those killed in the past. We can then expect suppliers fraudulently to claim that their illegal products actually fall into the legal category. Buyers are not harmed by this misrepresentation but some other policy is undermined. A modified inalienability rule-permitting gifts but not sales-may resolve both of these problems. ${ }^{14}$

Finally, difficulties of coordination may cause resources to be allocated inefficiently. This problem is closely related to the more pervasive problem of externalities, but because it has several distinctive features, I consider it as a separate category. The coordination problem arises most clearly in the case of pure public goods-urban parkland, for example-consumed in common by a large group. No one has an incentive to provide the efficient amount of this good because

12. See G. Calabresi, The Costs of Accidents (1970) (recommending that liability be placed on the cheapest cost avoider).

13. For a discussion of some of the problems with pricing policies, see Rose-Ackerman, Effluent Charges: A Critique, 6 Can. J. Econ. 512 (1973); Rose-Ackerman, Market Models for Water Pollution Control: Their Strengths and Weaknesses, 25 Pub. Pol. 383 (1977).

14. See infra notes 25-29 and accompanying text. 
the supplier bears all the costs and receives only a fraction of the benefits. Outlawing sales but permitting gifts is one way to achieve conservation while retaining considerable freedom for private action. ${ }^{15}$ Closely analogous to this case is the "prisoner's dilemma": all would benefit from coordinated action, but in the absence of coercion, independent action is inefficient. Consider, for example, the problem of coordinating the development of a new geographical region. Everyone is better off if other people have settled first, but no one has an incentive to be the first settler. To alleviate this problem, policymakers may attach coercive conditions such as a requirement that owners actually live on and develop the land in order to perfect their title. ${ }^{16}$

More narrowly focused coordination problems arise in controlling the opportunistic behavior of a person who purports to act on behalf of another. An inalienability rule may mitigate these problems when the law that directly controls the parties' relationship is inadequate. The law protects creditors, for instance, by preventing a person close to bankruptcy from giving away assets. Similarly, mineral leases that require payment of royalties equal to a percentage of the mining profits may include diligence requirements to induce leaseholders to search for resources.

The imposition of restrictions on alienability will, of course, generally have distributive as well as efficiency consequences. While analysts primarily concerned with efficiency may view a policy's redistributive impact as an unwelcome side effect, sometimes the distributive effects of a rule will be its primary justification. Because restrictions on transferability, ownership, and use single out a particular type of good or service for special treatment, these restrictions usually cannot be justified on broad redistributive grounds. Rather, the distributive case for inalienability is more narrowly focused. If policymakers wish to benefit a particular sort of person but cannot easily identify these people ex ante, they may be able to impose restrictions on the entitlement that are less onerous for the worthy group than for others who are nominally eligible. For example, the coercive conditions imposed on the use of land under the Homesteading Acts can be justified as a means of ensuring that the resource was transferred only to worthy recipientsin this case, formerly landless people willing to live on and farm the property for several years. ${ }^{17}$

Restraints on alienation also may have redistributive effects incidental to the primary justification for the policy. Restrictions justified on efficiency grounds frequently impose costs on a small or concentrated group, such as owners of land that has been down-zoned or owners of distilling equipment under Prohibition. Therefore, policymakers

15. See infra notes 21-24 and accompanying text.

16. See infra notes 73-77 and accompanying text.

17. See infra notes $81-82$ and accompanying text. 
must decide whether to compensate these losers. In some cases, the appropriate response to redistributive effects will be straightforward. Where policymakers believe that the affected group deserves to bear the costs of the policy, there should be no compensation. The group might, for example, be composed of people earning monopoly profits. Although economic discussions of monopoly power commonly stress the inefficiencies of markets with a single seller, a basic distributive principle generally seems to lurk behind these analyses. The principle is this: except as a reward for risk-taking, no one is entitled to profits that exceed the competitive rate of return because of market imperfections. Economic rents or earnings above this level can be confiscated by the state for redistribution to others. ${ }^{18}$ Compensation is also not justified if the owners accepted the risk of the restriction at the time of purchase. This expectation will have been reflected in the original purchase price, and it would be redundant to compensate the owners further. ${ }^{19}$ Conversely, compensation will be appropriate where there is no principled reason for the group to bear the costs of the policy and where doing so would not undermine the effectiveness of the restriction. For example, compensating owners of historic buildings for the costs of maintaining the structure's historical value would spread these costs among taxpayers without defeating the purpose of the restriction on use. ${ }^{20}$

Fundamental policy conflicts arise, however, when a group does not deserve to bear the costs of the restraint but where compensation would undermine the purpose of the restriction. For example, compensating blood donors for the fact that they cannot sell their blood would convert the process into something similar to a market trade and would undermine the use of a modified inalienability rule to assure high quality blood supplies. If the distributive costs are believed to be high in such situations, policymakers should consider alternatives to inalienability rules.

These issues are addressed first in the context of rules that restrict the transferability of entitlements (i.e., modified inalienability and modified property rules). I then examine rules that limit ownership and use and that may require certain actions as a condition for retaining a property right. Throughout the analysis I point first to market failures that may justify the use of inalienability rules and then discuss the most important distributive consequences.

18. Without this principle, antitrust laws and statutes that regulate public utilities would require the state to compensate monopolists for their loss of monopoly power. See Rose-Ackerman, Unfair Competition and Corporate Income Taxation, 34 Stan. L. Rev. 1017 (1982) (applying this argument in the context of competition between nonprofit and for-profit firms).

19. See Blume \& Rubinfeld, Compensation for Takings: An Economic Analysis, 72 Calif. L. Rev. 569 (1984); Wittman, Liability for Harm or Restitution for Benefit?, $13 \mathrm{~J}$. Legal Stud. 57, 65-66 (1984).

20. See infra notes $63-64$ and accompanying text. 


\section{B. Modified Inalienability Rule}

Modified inalienability provides a useful starting point because of the range of possible rationales for permitting gifts while outlawing sales. The most important efficiency justifications are: (1) conservation and supply management; (2) the regulation of close substitutes; and (3) the assurance of high quality output. I argue that each of the efficiency claims has merit in a restrictive range of circumstances but that using modified inalienability to achieve distributive goals is unjustified except to prevent monopoly gains.

I. Conservation and Supply Management. - The law may sometimes prohibit payment of suppliers because of the very responsiveness of supply to price that is the hallmark of a properly functioning market. The problem is an inefficiency caused by the market itself. If market trades are permitted, supply will be larger than under a modified inalienability rule. Suppose, however, that high levels of supply impose external costs on society, which are not reflected in market price. Outlawing sales is then a possible way to improve the allocation of resources. Two examples will illustrate this point: population control and the conservation of wild animals and primitive cultures.

Those concerued with the social costs of overpopulation may wish to restrict the freedom of individuals to decide how many children to bring into the world. They may not only support family planning, subsidized abortions, and birth control but also oppose a legalized market in adoptions. They may want to prohibit the sale of babies for fear that women will produce children for profit, thus exacerbating the problem of overpopulation. As Robert Pritchard notes, however, the prohibition has resulted in shortages of newborn children available for adoption, thereby "leaving many couples deprived of the privileges and joys of child rearing." 21 Thus he raises the issue of concentrated costs to justify using the market even in this context. The difficulty with this argument is that even with a legal adoption market some people will be unable to adopt children because the price will be too high. All adoption policies have distributive consequences for both parents and children. It is not at all obvious, for example, that children themselves would generally be worse off if the sale of newborn infants were permitted. So long as an adoption market is not ruled out ex ante on moral

21. Pritchard, A Market for Babies?, 34 U. Toronto L.J. 341, 342 (1984). But cf. Landes \& Posner, The Economics of the Baby Shortage, 7 J. Legal Stud. 323 (1978) (defending a market for adopted children). The "sale" of children is not entirely illegal. Although outright sales are forbidden, "family compacts" in which a mother gives up her child in return for promises of monetary support either for herself or for herself and her child have been upheld in some jurisdictions so long as the arrangement promotes the child's welfare. See, e.g., Clark v. Clark, 122 Md. 114, 89 A. 405 (1913) (mother permitted to give up her child to her wealthy father-in-law in return for his agreement to support the mother for life); Enders v. Enders, 164 Pa. 266, 30 A. 129 (1894) (upholding a grandfather's promise to raise his grandson in return for payments to his son's wife and to the child). 
grounds, the issues are largely empirical: How responsive is supply to price? What would be the impact on children and on prospective parents? How would the costs and benefits be distributed?

Consider next the conservation of wild animals. Conservation objectives may be furthered by preventing the commercial exploitation of endangered species through laws that permit the use of the resource for fun (or survival), but not for profit. The best American example is the regulation of wild fish and game resources. It would not violate public policy with respect to fish and game if a hunter, while on a vacation trip, happened to be lucky, shot more pheasants than he could use, and sold a few to friends. If sales were permitted, however, other people might decide to take up hunting because of the profitable opportunities available. Thus, a number of states have rules against sales. ${ }^{22}$ These laws facilitate conservation by discouraging the entry of profit seeking hunters or fishermen.

A similar problem arises when the state wishes to preserve a group's way of life. Once again, a modified inalienability rule can help accomplish this aim. Recent federal laws and treaties preserve the right of Eskimos and other Alaskan natives to hunt certain kinds of game in spite of more stringent controls on the general public. ${ }^{23}$ These native groups are, however, sometimes prohibited from selling their catch. ${ }^{24}$ Without such a prohibition, outsiders and profit-motivated tribal leaders might invest in the tribe's activities and in the process both destroy tribal life and undermine the conservationist aims of the general prohibitions.

22. See, e.g., Me. Rev. Stat. Ann. tit. 12, §§ 7452(9)(A), 7456(5), 7457(3), 7615 (1964 \& Supp. 1984-85); N.Y. Envtl. Conserv. Law \$§ 11-0536, -1319(2), -1705(10), -1729 (McKinney 1984 \& Supp. 1984-85); Tex. Parks \& Wild. Code Ann. §§ 65.102, $66.111,76.039$ (Vernon 1976 \& Supp. 1985); Wis. Stat. Ann. $\S \S 29.415(4), 29.48$ (West 1976 \& Supp. 1984-85); cf. Mass. Ann. Laws ch. 131, §§ 22, 25, 26A (Michie/Law. Coop. 1972 \& Supp. 1985) (excepting a few fur-bearing animals); Va. Code \$§ 29-154, $-161.1,-164$ (1979 \& Supp. 1984) (same).

23. Eskimos are explicitly exempted from some provisions of both the Endangered Species Act of 1973, 16 U.S.C. $\$ 1539$ (e) (1982), and the Marine Mammal Protection Act of 1972, 16 U.S.C. $\$ 1371$ (b) (1982). Certain treaties permit American Indians to take migratory bird species for food and clothing but not for sale. See Convention Between the United States and Great Britain for the Protection of Migratory Birds, Aug. 16, 1916, art. Il, $\S(1),(3), 39$ Stat. 1702, T.S. No. 628; Convention for the Protection of Migratory Birds and Birds in Danger of Extinction and Their Environment, Mar. 4, 1972, art. 11I, $\S 1$ (e), 25 U.S.T. 3329, T.I.A.S. No. 7990. Only one federal law gives Indians an explicit exemption. See Bald Eagle Act of 1940, ch. 278, § 4, 54 Stat. 251 (codified as amended at 16 U.S.C. $\$ 668$ a (1982)) (allowing lndians to obtain permits to kill eagles for religious purposes). See generally Coggins \& Modroin, Native American Indians and Federal Wildlife Law, 31 Stan. L. Rev. 375 (1979) (exploring the conflict between Indian rights and federal wildlife law).

24. Under both the Endangered Species Act and the Marine Mammal Protection Act, Alaskan natives may hunt endangered or threatened species if these are used "primarily" for subsistence or are made into "authentic native articles of handicrafts and clothing." 16 U.S.C. $\$ \S 1317$ (b), 1539(e) (1982). 
2. Regulating Close Substitutes. - Sometimes a free market has no adverse effects on the production and distribution of a good but instead complicates some other public policy. For example, if it is difficult for buyers and law enforcement officials to distinguish between a forbidden good and a close substitute, preventing sale of the substitute can aid enforcement of a law against possession or transfer of the forbidden good. To illustrate, consider the use of modified inalienability rules in the Endangered Species Act and the Migratory Bird Treaties. Since there is apparently no reliable way to date stuffed animals, fur, feathers, ${ }^{25}$ and most other animal products, enforcement is simplified if the law prohibits all sales of a species, not just the sale of animals killed after the law's effective date. ${ }^{26}$

When a modified inalienability rule makes the administration of a law inexpensive and convenient, there is a strong argument for compensating those who find that their possessions have unexpectedly fallen in value. Otherwise the state would not need to take into account

25. See Andrus v. Allard, 444 U.S. 51, 58 (1979). Plaintiffs, however, claimed that even if feathers could not be dated, "feathered artifacts" (e.g., Indian headdresses) could be dated. Id.

26. In United States v. Richards, 583 F.2d 491 (10th Cir. 1978), both the majority and the dissent recognized that an Interior Department rule defining migratory birds to include those raised in captivity is administratively convenient "since it is impossible in most cases to determine whether the bird in the hunter's bag is one raised in captivity or taken from the wild." Id. at 497 (Logan, J., dissenting). The court upheld the regulation and rejected the argument that prohibiting sales of captive birds would reduce the supply. Id. at 496 .

In Delbay Pharmaceuticals v. Department of Commerce, 409 F. Supp. 637 (D.D.C. 1976), brought under the Endangered Species Act, the Commerce Department seized Delbay's inventory of imported spermaceti. Delbay argued that it should be able to sell its spermaceti because it was imported before the law went into effect. In rejecting Delbay's claim, the court emphasized administrative difficulties: "If plaintiff's spermaceti were allowed to enter interstate commerce, it could greatly increase the enforcement difficulties. A total ban is easier to enforce than a partial ban. If there were a continued market in this country for spermaceti, it might encourage the illegal taking of sperm whales to supply this market." Id. at 642.

Similarly, in Andrus v. Allard, 444 U.S. 51 (1979), the Supreme Court upheld a prohibition on the sale of eagles and products made of eagle feathers even though the eagles were killed before the law went into effect. Gift giving, however, was expressly permitted by the Court. See id. at 66; see also United States v. Hamel, 534 F.2d 1354, 1356 (9th Cir. 1976) (requiring government to prove that a bird was killed after the Migratory Bird Treaty Act took effect would undermine the purpose of the Act).

An early district court decision, in contrast, rejected administrative convenience as a rationale for the Migratory Bird Treaty Act. See United States v. Fuld Store Co., 262 F. 836 (D. Mont. 1920). In upholding a person's right to hold and sell items made from heron feathers, the court argued that "[a]n intent on the part of Congress to virtually outlaw and destroy such property ought not to be assumed, unless very clear and the only reasonable construction of the act; for it is very doubtful if Congress has any such power . . . . [S]ome incidental advantage in administration of the law . . . avails nothing." Id. at 837-38; see also In re Informations Under Migratory Bird Treaty Act, $281 \mathrm{~F}$. 546 (D. Mont. 1922) (construing Act not to apply to transactions involving birds taken before effective date). 
the full costs of its policy, and a group that is unlucky enough to own a close substitute for the regulated product bears a disproportionate share of the cost. The case of Andrus v. Allard ${ }^{27}$ provides an example. The statutes at issue prohibited the killing of eagles after a certain date. To ease the administration of the statutes, the Secretary of the Interior issued regulations prohibiting the sale of eagles killed before that date. The effect of the prohibition was to reduce the value of lndian artifacts made of "old" eagles by changing the owners' legal entitlement from a pure property rule to a modified inalienability rule. The owners challenged the statutes on the grounds that they constituted an unconstitutional "taking" of property requiring payment of compensation. ${ }^{28}$

The Supreme Court accepted the administrative convenience rationale behind the Interior Department regulations and rejected the owners' compensation claims on the ground that no "taking" had occurred. The government had not "physical[ly] inva[ded]" the owners' property, and had prevented only "one means of disposing of the artifacts." 29 The Court, however, never directly faced the important issue of whether the payment of compensation would undermine the reasons for promulgating the rule in the first place. In particular, in setting up a compensation scheme, the Interior Department would have faced the problem of distinguishing between legitimate holders of "old" eagle feathers and those making dishonest claims. In fact, however, a number of alternatives were open to the Interior Department that would have provided some form of compensation without undermining the legislative purpose. Before the protective law took effect, for example, holders of eagles and eagle feathers could have been required to obtain licenses certifying the legality of their holdings. Sales would then have been legal only if owners had licenses. Alternatively, the government might have stood ready to purchase all specimens presented to it by a certain date, or licensed holders could have retained possession but been paid compensation.

3. Quality Control. - In an influential book on human blood, Richard Titmuss ${ }^{30}$ argues for modified inalienability on quality control

27. 444 U.S. 51 (1979).

28. Id.

29. 1d. at 65. In addition to possession and transportation of their property, the owners could also "donate or devise the protected birds" and could "exhibit the artifacts for an admissions charge." Id. at 66.

In a related case involving a man who raised falcons, a court determined that because the defendant raised hawks under permits-first from Wisconsin and then from Utah-" [h] is permissive possession of the birds did not carry with it the traditional incidences of property rights. . . . At the most the states granted a partial property interest which did not encompass all usual property rights." United States v. Richards, 583 F.2d 491, 498 (IOth Cir. 1978). Accordingly, the claim of unconstitutional deprivation of property was denied.

30. R. Titmuss, The Gift Relationship: From Human Blood to Social Policy (1971). 
grounds. The argument, developed further by Kenneth Arrow, ${ }^{31}$ views modified inalienability as a response to the general problems created by markets with imperfect information. If it is difficult for hospitals to judge whether blood contains the damaging hepatitis virus, while individuals know their own health history, then ideally one would design a collection system that gives contributors an incentive to reveal any past cases of hepatitis. ${ }^{32}$ On the one hand, if people are paid for their blood, they may try to hide damaging information. On the other hand, if they are induced to donate their blood for altruistic reasons, those who have had hepatitis presumably will not make contributions. Of course, there may well be other systems of property rights-such as sale followed by liability for damages, ${ }^{33}$ labelling by source, ${ }^{34}$ or more careful selection of donors ${ }^{35}$ - that respond to the quality control problem. But a purely voluntary system is, at the very least, a method worthy of serious consideration. ${ }^{36}$

31. Arrow, Gifts and Exchanges, 1 Phil. \& Pub. Aff. 343 (1972).

32. New tests do permit better screening for hepatitis $A$ and $B$, but existing procedures are still not effective for Non-A, Non-B hepatitis. See Non-A, Non-B Hepatitis, 2 The Lancet 1077 (1984). Recent concern about the transmission of A1DS through blood transfusion has raised similar issues even in the context of donated blood. See Chase, "Gift of Life" May Be Also an Agent of Death in Some AlDS Cases, Wall St. J., Mar. 12, 1984, at 1, col. 1; Results of AIDS Tests, N.Y. Times, Mar. 26, 1985, at C2, col. 5 (describing a new test that is still not completely reliable).

33. See Kessel, Transfused Blood, Serum Hepatitis, and the Coase Theorem, 17 J.L. \& Econ. 265 (1974).

34. Food and Drug Administration regulations require blood to be labeled "paid donor" or "volunteer donor." R. Scott, The Body as Property 194 (1981).

35. See M. Cooper \& A. Culyer, The Price of Blood (1968); Sapolsky \& Finkelstein, Blood Policy Revisited-A New Look at "The Gift Relationship," 46 Pub. Interest 15 (1977).

36. The law on this subject varies. The Uniform Anatomical Gift Act (UAGA), 8A U.L.A. 15 (1983), which has been adopted by all fifty states and the District of Columbia, treats only gifts from dead bodies; it does not resolve the legal status of sales from either the living or the dead. A commissioner's note to $\$ 3$ states: "The statutes in a few states specify that no donor shall ask compensation and no donee shall receive it. Several statutes provide that storage banks shall be non-profit organizations. On the other hand, most of the states have chosen not to deal with this question. The Uniform Act follows the latter course in this regard." Id. at 41 ; see also Stason, The Uniform Anatomical Gift Act, 23 Bus. Law. 919, 927-28 (1968) (noting that the UAGA does not address the issue of payment for gifts of body parts); cf. Note, Retailing Human Organs Under the Uniform Commercial Code, 16 J. Mar. L. Rev. 393 (1983) (advocating amendments to the UAGA to permit the sale of organs).

Russell Scott reports that in the late 1960s, Nevada, Delaware, Hawaii, New York, and Oklahoma passed laws banning payment to a person while alive for his or her body parts after death, but these laws did not prohibit the sale of the organs by next of kin. $R$. Scott, supra note 34, at 190. In 1969, Mississippi "authorized its citizens to sell their body parts to hospitals, which were given the right to take possession upon death. Breach of the contract necessitated repayment of the money plus interest at six percent." Id. In 1969, Massachusetts "prohibited payment to any person for any cadaver organ." Id. Scott goes on to note that most of these restrictions were abolished when the UAGA was passed "since the act was believed to exclude all sales," id., an interpreta- 
The argument for modified inalienability, however, is not without weaknesses. First of all, the quality control benefits of gift giving operate only on the supply side of the market. Thus, once the blood has been collected, there is no quality control argument against selling the blood to patients. ${ }^{37}$ One cannot contend that paying customers are generally less likely to make effective use of blood transfusions than are other users. Such a dual system may not be feasible, however. Quite simply, gifts may not be forthcoming if donors know that the collection agency is selling their gifts ${ }^{38}$ and do not consider the collection agency to be a worthwhile charity. ${ }^{39}$ Second, even if the blood is of high quality, the supply of donations may be insufficient to meet the demand. This problem can be mitigated by paying donors' expenses, ${ }^{40}$ insuring them against future medical complications, ${ }^{41}$ or providing other forms of compensation that lower the cost of donating without permitting individuals to profit financially from their blood. ${ }^{42}$ Since such expedients may not always be effective, however, undersupply may continue to be a serious potential problem.

Moreover, even if a system of voluntary blood donations proves workable, the Titmuss proposal should not be unthinkingly generalized. Blood is a very special commodity. Once a person gives or sells some blood, more is produced "automatically" so long as the person has not sold or given away so much as to injure his health. The quality of the blood produced is not affected by the price at which it can be

tion at odds with that of the commissioners. The Delaware UAGA explicitly prohibits sales. See Del. Code Ann. tit. 24, § 1783(f) (1981).

37. See M. Cooper \& A. Culyer, supra note 35; cf. G. Calabresi \& P. Bobbitt, Tragic Choices 19-22 (1978) (distinguishing between first- and second-order determinations, i.e., between how much will be produced and who will get it).

38. See R. Titmuss, supra note 30 , at 151 ("Altruistic donors can hardly be expected to give their blood to profit-making hospitals.").

39. This problem is not unsolvable. One could, for example, imagine churchs or day care centers raising money by selling donated blood just as they now sell donated food, clothing, and household goods. Blood banks could merge with charities or give their proceeds to the United Way.

40. See Council of Europe, Committee of Ministers, Harmonisation of Legislations of Member States Relating to Removal Grafting and Transplantation of Human Substances, Resolution (78)28, adopted 11 May 1978 \& explanatory memorandum 29. Article 9 states that "[n]o substance may be offered for profit. However, loss of earnings and any expenses caused by the removal or preceding examination may be refunded." Council of Europe, Committee of Ministers, International Exchange and Transportation of Human Substances, Recommendation R(79)5, adopted 14 Mar. 1979 \& explanatory memorandum, favors outlawing sales of human tissue but authorizes payment for shipping expenses.

41. See, e.g., Comment, California's Response to the Problem of Procuring Human Remains for Transplantation, 57 Calif. L. Rev. 671, 692 (1969) (recommending that both donors and patients be insured).

42. Compensation may take the form of promises to supply blood in the future if donors or their families need it, or to make gifts in the donors' names to charities of their choice. R. Titmuss, supra note 30 , at $78-88$. 
sold, and the quantity inside people's veins is always sufficient to meet the demand. Thus, the only quality control problem is the proper selection of suppliers. Furthermore, with the exception of a few people with rare blood types, there is no monopoly power problem. ${ }^{43}$ Suppose, in contrast, that the market for used cars were outlawed and the Salvation Army encouraged people to donate cars for distribution to the needy. Since cars do not spontaneously regenerate themselves in the garages of the altruistic, it appears unlikely that many high quality cars will be given away. Yet automobiles are like blood in that individual owners know more about the quality of their cars than the buyers or donees can easily find out. ${ }^{44}$ Even if a purely voluntary system would induce people with "lemons" to throw them away rather than donate them, the overall quantity and quality of used cars would be low.45 As another example, suppose that the military only wanted patriotic fighters to join the armed forces but had no good way to test for patriotism. It might try accordingly to establish a volunteer army that paid only subsistence wages. This plan would be unlikely, however, to attract more than a few super-patriots, and most volunteers might instead be unemployed people with very low skill levels.

4. Blood, Body Parts, and Fairness. - Many people oppose the sale of blood to patients on the ground that it is unfair to allocate a basic necessity of life on the basis of ability to pay. In a competitive market, this argument seems difficult to sustain for two reasons. First, the distributive arguments against sales may not be strong enough to overcome the inefficiency of nonmarket transactions. Making free a good that actually has an opportunity cost will produce excess demand, since the value of the good to marginal consumers will exceed its marginal cost. If, in addition, suppliers are not reimbursed, quantity will be inefficiently low. Second, there may not be any distributive reason for treating the good in question differently from close substitutes. Artifcial limbs are for sale, but not real kidneys. On purely distributive grounds it seems unfair to treat people whose problem requires a mechanical or chemical solution differently from those who need living tissue. In the field of health, such distinctions seem particularly problematic, since most people are covered by public or private health

43. Cf. United States v. Garber, 607 F.2d 92 (5th Cir. 1979) (tax treatment of the earnings of a woman whose blood plasma contained a rare antigen useful to drug manufacturers).

44. The problem of low quality used cars forcing good ones out of the marketplace is analyzed in Akerlof, The Market for "Lemons": Quality Uncertainty and the Market Mechanism, 84 Q.J. Econ. 488 (1970).

45. Cf. Rottenberg, The Production and Exchange of Used Body Parts, in 2 Toward Liberty: Essays in Honor of Ludwig von Mises 322 (1971). Rottenberg criticizes doctors who refuse to transplant purchased organs or use purchased blood. "It is as though a coalition of plumbers had agreed that none of them would install bathroom fixtures that a household had secured in exchange for money but only those altruistically given away by appliance manufacturers." Id. at 327. 
insurance. ${ }^{46}$

If the market is not competitive, however, the distributive arguments against sales may have more merit. The monopoly power issue arises most clearly in the provision of human tissue. Because overall supply is not affected by market structure, monopoly power only affects the distribution of benefits between donor and donee. Thus, if tissue typing shows that your kidney is the best one to transplant into your cousin, a bilateral monopoly situation is created, ${ }^{47}$ and if sales are permitted, you might hold out for a large payment in return for saving your cousin's life. Similarly, some types of rare antibodies are only available from a few people and are extremely valuable in the production of certain drugs. ${ }^{48}$ In such contexts, an entirely unregulated market could have undesirable distributive consequences if people exercise their monopoly over scarce bodily tissues and antibodies at the expense of the sick. Prohibiting sales is not, however, the only response to the problem. One could instead imitate the policy followed in more conventional cases of monopoly power by permitting sales but regulating prices so that they reflect the marginal costs and risks borne by the donor. ${ }^{49}$

\section{Modified Property Rule}

In contrast to modified inalienablity rules, modified property rules are relatively uncommon and apply to particular situations rather than types of goods and services. Under such rules, property may be sold at market prices but cannot be given away. Most commonly, modified .

46. Even if a persuasive argument can be made against selling the entitlement to users, it may still be possible to obtain some of the benefits of market transactions by having the state purchase the good or service from suppliers for free distribution to the public based on nonmarket criteria. Thus, if there is an inadequate supply of organs from cadavers for transplant under an entirely voluntary system, people could be paid by the state for promising to donate their organs with the allocation based on medical judgment. Of course, if this change in practice substantially increases supply, then the need for difficult distributive choices by hospitals and doctors will be reduced since supply will more nearly equal demand. For proposals along these lines, see Brams, Transplantable Human Organs: Should Their Sale Be Authorized by State Statutes?, 3 Am. J.L. \& Med. 183 (1977); Dukeminier, Supplying Organs for Transplantation, 68 Mich. L. Rev. 811 (1970); Sanders \& Dukeminier, Medical Advance and Legal Lag: Hemodialysis and Kidney Transplantation, 15 UCLA L. Rev. 357 (1968); Note, Compulsory Removal of Cadaver Organs, 69 Colum. L. Rev. 693 (1969); Note, The Sale of Human Body Parts, 72 Mich. L. Rev. 1182 (1974).

47. See, e.g., Strunk v. Strunk, 445 S.W.2d 145 (Ky. 1969); McFall v. Shimp, 10 Pa. D. \& C.3d 90 (1978).

48. See, e.g., United States v. Garber, 607 F.2d 92 (5th Cir. 1979).

49. Of course, other personal attributes that give people monopoly rents are not so regulated: great beauties, highly skilled athletes, and geniuses frequently earn monopoly profits. One problem with taxing the returns to beauty, strength, and intelligence, however, is that individuals should be given an incentive to develop their natural gifts. In contrast, although people can be compensated for the time, trouble, and risk of organ removal, they cannot affect their tissue type. 
property rules have been imposed on people who are either insolvent or about to die. In both cases, these rules solve problems that arise because someone with an interest in the property has no formal legal claim until some event, i.e., bankruptcy or death, occurs. These diffculties are examples of the agency-principal problems familiar to economic analysts in contexts as different as shareholder control of corporate managers and the relationship between insurance companies and their customers. ${ }^{50}$ The restriction on gifts substitutes for laws that directly control the relationship between the parties. The modified property rule is a second-best way of recognizing the property interests of creditors, heirs, and tax collectors in situations where the nominal owner may choose to overlook their claims.

Consider bankruptcy law first. Gifts made before a declaration of bankruptcy are condemned as "fraudulent conveyances," but sales of assets are legal so long as "reasonably equivalent value" is received.51 Without this restriction on gifts, a person who became insolvent could simply give away all his assets to family and friends, go bankrupt, and then accept reciprocal gifts from them afterwards. This practice would introduce an element of risk into the making of loans that would serve no productive purpose. Ex ante the volume of loans would be inefficiently low and interest rates inefficiently high to take account of this possibility of hiding assets from creditors.

In contrast, prohibitions on gifts made close to the time of death can be justified mainly on distributive grounds. Originally, such rules protected heirs against pressure applied by clerics and doctors to dying relatives. ${ }^{52}$ At present, the laws of most states and the federal government do not prevent gifts made close to the time of death. However, a weak form of modified property rule remains the legal standard for death related transactions: certain gifts made within three years of death are treated as part of one's estate for tax purposes. The purpose of this rule is to protect the state against the tax avoidance activities of

50. See, e.g., Ross, The Economic Theory of Agency: The Principal's Problem, 63 Am. Econ. Rev. (Papers \& Proceedings) 134 (1973); Shavell, Risk Sharing and Incentives in the Principal and Agent Relationship, 10 Bell J. of Econ. 55 (1979).

51. 11 U.S.C. § 548(a) (1982). See generally J. Hanna \& J. MacLachlan, Cases \& Materials on Creditors' Rights and Corporate Reorganization 204-22, 233-55 (1957) (discussing the Uniform Fraudulent Conveyance Act and providing excerpts from the leading cases).

52. In Louisiana, for example, gifts to either doctors or "ministers of religious worship" cannot be made by a sick person who dies of his illness. The person may, however, pay for services rendered. La. Civ. Code Ann. art. 1489 (West 1952). In Georgia, no one with a spouse or child may devise more than one-third of her estate to charitable or religious institutions if the will is executed within $\mathbf{9 0}$ days of the person's death. Ga. Code Ann. §53-2-10 (1982). Similarly, old treatises on gifts note that a gift to one's "spiritual adviser" will be regarded with suspicion by courts especially if made mortis causa. See, e.g., W. Thornton, A Treatise on the Law Relating to Gifts and Advancements 456 (1893). 
dying individuals and their heirs. ${ }^{53}$

\section{Limits on Ownership and Use}

Restrictions on ownership and use will sometimes be effective second-best substitutes for more flexible, incentive-based systems of externality control. In this section, 1 consider a wide range of such restrictions, from limits on who may drive automobiles to controls on the use of historic buildings and undeveloped land. In practice, of course, externality control is not a central reason for many existing limitations. Instead, they are based on paternalistic motives or are blatantly designed to create monopoly rents. My purpose is not to justify such restrictions but rather to indicate the narrow range of cases where economic efficiency may be furthered by limiting who may use or own a product and what may be done with it.

I. Restrictions on Ownership. - Ownership restrictions work in conjunction with the tort law system to prevent conduct dangerous to third parties. ${ }^{54}$ They prevent groups of people, e.g., people under sixteen or those with diabetes, from owning certain goods or engaging in certain activities, e.g., purchasing liquor, driving a car, or obtaining a pilot's license. Inalienability rules of this kind are second-best methods of control because they treat all members of a group alike. These restrictions thus are likely to be both over- and underinclusive. In contrast, a tort law system, requiring compensation ex post, can be sensitive to individual differences in behavior but may be costly and time-consuming to implement. In practice, we have a mixed system which combines ex ante restrictions with ex post liability. Tort law emphasizes those practices that are inherently most difficult to measure ex ante. For example, while tests of driving ability, knowledge of traffic laws, and color blindness determine who will obtain a driver's license, the possibility of a tort suit after an accident is likely to deter people from driving carelessly.

The use of statistical evidence to sort out applicants is efficacious if the measuring rod is directly related to behavior. Proxies are often used, however, because of measurement difficulties. Simple criteria such as age can often be understood as substitutes for more complex criteria such as health status or ability where problems of measurement

53. In recent years the consolidation of the gift and estate tax systems has mooted the problem of determining intent. Yet, since the federal government taxes gifts differently from sales, it becomes important to define a sale. Within three years of death, the IRS will scrutinize sales to be sure that "adequate consideration" in money or money's worth has been received. If the IRS is not satisfied, the balance will be taxed as if it were a gift. See T. Englebrecht, M. Moore \& A. Fowler, Federal Taxation of Estates, Gifts and Trusts 61-66 (1981).

54. See generally Calabresi, Torts-The Law of the Mixed Society, 56 Tex. L. Rev. 519 (1978) (examining the roles of the tort system and direct regulation of behavior in controlling risk). 
ex ante and of attributing causation ex post are likely to be serious. Thus, if there is a strong statistical relationship between the age of an automobile driver and the probability of being in an accident, the state can forbid people below a certain age from driving cars instead of designing a costly individualized test to sort out the careful children. Costs are imposed on careful children by this method of accident prevention, but they must be balanced against the costs of more discriminating tests. ${ }^{55}$

There are limits to this method, however. We seem to be reluctant to use statistical patterns to distinguish between people on the basis of demographic criteria beyond their control. Thus, we do not allow white women to drive at an earlier age than males and blacks, even though the statistical evidence shows that white women are safer drivers. ${ }^{56}$ Age, however, is less suspect than race or gender since all people age at the same rate and is, therefore, frequently used as a basis for distributing benefits and burdens. Furthermore, even though a demographic characteristic is something over which an individual has no control, it may still be used to distinguish between people if the causal link is well established and close to being deterministic. Thus, diabetics may be prevented from obtaining commercial pilots' licenses or driving trucks with hazardous cargoes, and color-blind people may be unable to obtain drivers' licenses. ${ }^{57}$

Ideally, people should be compensated for unfair burdens resulting from the use of statistical regularities instead of individual behavior. Compensation is impossible, however, for just the reason that statistical

55. Another factor is whether the tests will in fact screen effectively. Some states attempt to screen out more careful younger drivers by requiring that 16 and 17 yearolds complete driver education courses before obtaining licenses. See, e.g., Cal. Veh. Code $\S 12057$ (West 1971). At 18, anyone who passes the state test can obtain a license. See, e.g., id. § 12512. Two commentators have argued, however, that such statutes achieve precisely the opposite result: increasing the number of 16 and 17 year-old drivers increases the automobile accident death rate. See Robertson \& Zador, Driver Education and Fatal Crash Involvement of Teenaged Drivers, 68 Am. J. Pub. Health 959 (1978).

56. See Underwood, Law and the Crystal Ball: Predicting Behavior with Statistical Inference and Individualized Judgment, 88 Yale L.J. 1408, 1434-42 (1979) (distinguishing between measures beyond the control of people and those that can be affected by their behavior). The most prominent suspect criteria are race, sex, and national origin. See U.S. Const. amend. XIV, § 1; Civil Rights Act of 1964, 42 U.S.C. $§ 2000$ a (1982); Equal Employment Opportunity Act, 42 U.S.C. § 2000e (1982). Other criteria include age, see Age Discrimination in Employment Act of 1967, 29 U.S.C. § 621 (1982), Age Discrimination Act of 1975, 42 U.S.C. \$ 6101 (1982), and physical handicap, see Rehabilitation Act of 1973, 29 U.S.C. \$ 701 (1982), Developmental Disabilities Assistance and Bill of Rights Act, 42 U.S.C. $\$ 6000$ (1982).

57. Because of a concern for accident risks, the Federal Highway Administration prohibits diabetics on insulin from driving trucks in intercity or interstate commerc

See Hricko, Drivers of Hazardous Cargoes-Legal Aspects of a Maximum Age and Increased Physical Requirements, 31 Fed'n Ins. Couns. 126, 130 (1981). New York City taxi drivers are similarly restricted. N.Y. City Admin. Code, ch. 65, § 2305 (1975). 
evidence is used initially to limit ownership and use: individual distinctions are costly or impossible to make.

Even though I have treated ownership restrictions as a second-best response to controlling externalities, I have idealized their role. In practice, such restrictions frequently are designed to give some profession or occupation monopoly power. It is, for example, very difficult to argue that most professional licensure laws are primarily concerned with quality control. ${ }^{58}$ Simple restrictions on the number of market participants also are generally explicit grants of monopoly power to a limited group. While limits on the number of taxicabs in a city may reduce traffic congestion, they also benefit license holders; 59 restrictions on the number of bank offices in a state ${ }^{60}$ do not even have a limited market failure rationale. Thus, while a combination of externality control and administrative convenience may justify some restrictions, the possibility of such a justification should not create a presumption in favor of these regulations.

2. Required Use. - Some entitlement regnlations require a small set of actions while permitting a wide range of other uses. As a condition for retaining ownership, the law may mandate actions that produce positive externalities. These regulations substitute for market-oriented systems that pay a subsidy set equal to the external benefits such actions produce.

58. Cf. Stigler, The Theory of Economic Regulation, 2 Bell J. Econ. \& Mgmt. Sci. 3, 13-17 (1971) (occupational licensing uses the political process to improve a group's economic circumstances); Brill, Protection for the Hard of Hearing: State and Federal Regulation of Hearing Aid Dealers, 27 DePaul L. Rev. 45, 86-87 (1977) (boards "dominated by members of the industry" help thwart statutory purpose of protecting hard of hearing).

59. Given the casual, short-term nature of individual taxi rides, state regulation of some aspects of quality appears justified. Thus both Chicago and New York require that vehicles be safe to operate. In New York inspections are required every four months, and vehicles must be equipped with emission control devices. Similarly, in both cities, drivers must have a special taxi driver's license that requires them to be in sound physical condition and of good moral character. In New York the law states that applicants will be examined on their knowledge of the city. See N.Y. City Admin. Code, ch. 65, $\S \S 2301-2319$ (1975). Although these restrictions on the ownership and use of taxicabs appear justified on efficiency grounds, limitations on entry, which are less easy to justify, accompany them. See Kitch, Isaacson \& Kasper, The Regulation of Taxicabs in Chicago, 14 J.L. \& Econ. 285 (1971).

60. See generally Note, Bank Charters, Branching, Holding Company and Merger Laws: Competition Frustrated, 71 Yale L.J. 502 (1962) (summarizing laws governing entry into banking). Some statutes and court decisions, however, seek to foster competition. See, e.g., Moran v. State Banking Comm'r, 322 Mich. 230, 243, 33 N.W.2d 772, 778 (1948) (charter statute should be used "not to deter competition or foster monopoly, but to guard the public and public interest against imprudent banking") (quoting State ex rel. Dybdal v. State Sec. Comm'n, 145 Minn. 221, 224-25, 176 N.W. 759, 760 (1920)); Central Bank v. State Banking Bd., 509 S.W.2d 175, 184 (Mo. Ct. App. 1974) (convenience and needs standard does not contemplate preventing new banks "from entering a market because existing banks are rendering adequate service"); Bank Holding Company Act of 1957, § 1, Ill. Ann. Stat. ch. 17, § 2501 (Smith-Hurd 1981). 
Two examples are especially interesting: historical preservation and preservation of the habitats of endangered species. Historical preservation statutes typically require that owners preserve at least the facades of certain buildings. Permission is required for any alterations to the affected portions of the building and demolition is permitted only under very restricted conditions. For example, the New York City Landmarks Preservation Law emphasizes the protection and preservation of external architectural features and internal features, such as building lobbies or auditoriums, that are open to the public, and it only rarely allows demolition. ${ }^{61}$ Similarly, the Endangered Species Act may require landowners to avoid destroying the habitat of an endangered species. ${ }^{62}$ Both of these policies can be justified by the external benefits of maintaining the affected property in its original form.

Two problems militate against regulatory statutes that require preservation. First, they may lead to too much or too little preservation because the government's criterion of value will not always equal the opportunity costs of foregone development. Second, in the absence of countervailing subsidies, the cost of preservation is borne by those who own the property at the time the law is promulgated, unless, of course, the law actually increases property values. ${ }^{63}$ But both the problem of inefficient preservation and the problem of concentrated costs can be avoided by a law that pays owners a bounty to preserve their land or buildings. This system could be more efficient than outright prohibitions if the bounty were set equal to the external benefits of preservation. Historical buildings would be torn down and habitats destroyed only if their external benefits were too low to justify their preservation given the land's alternative uses. ${ }^{64}$ Although in practice quantifying these benefits is very difficult, attempts to do so will frequently be preferable to required use regulations when the effect of the latter is to impose all the costs on the producer of the social benefits.

3. Limits on Use. - Conversely, other laws forbid certain activities in an attempt to limit negative externalities. For example, land use

61. N.Y. City Admin. Code, ch. 8-A, §§ 207-1.0(g), (m), (n), $-5.0(\mathrm{a}),-6.0,-10.0$ (1976). The law's basic purpose is outlined at $\S 205-1.0(\mathrm{~b})$.

62. A recent court of appeals decision can be read to support this view even though it dealt with the State of Hawaii rather than private landowners. See Palila v. Hawaii Dep't of Land \& Natural Resources, 639 F.2d 495 (9th Cir. 1981); Note, Palila v. Hawaii Department of Land $\Xi$ Natural Resources: A New Interpretation of "Taking" Under the Endangered Species Act of 1973, I9 Idaho L. Rev. 157 (1983) (arguing for a broad reading of the Palila case).

63. D. Listokin, Landmarks Preservation and the Property Tax (1982), summarizes recent research, including evidence on both increases and decreases in property values under historical preservation statutes. Rose, Landmarks Preservation in New York, Pub. Interest, Winter 1984, at 132, 142, argues in favor of compensation. Rough approximations of this policy are property tax reductions, rapid depreciation of rehabilitation expenses and, in urban areas, markets in air rights. See Pennsylvania Cent. Transp. Co. v. New York City, 438 U.S. 104 (1978).

64 . See Wittman, supra note 19 , at 75 . 
zoning laws may prevent owners from using their land for certain things such as a store or a factory but may permit apartment buildings so long as maximum density requirements are met and sewer and water lines are provided. ${ }^{65}$ Zoning laws do not require development as a condition of ownership; rather, their economic function is to control the externalities of development if it occurs.

Here too, the regulations are second-best substitutes for a policy that balances the benefits and costs of development in individual cases. ${ }^{66}$ They also have some of the same undesirable distributive costs as laws requiring certain actions. Once again, those who own the land at the time the zoning law is passed bear the cost along with those who would have benefited if the property had been put to its most profitable use. The purchase of development rights by government is a noncoercive alternative to zoning that forces the state to take into account the costs of restricting land use. In a few jurisdictions this policy has been applied to farmland. ${ }^{67}$

\section{E. Coerced Use}

I use the term "coerced use" to apply to situations in which all permitted activities are also required. When the government sells, leases, or gives property to private individuals, the state may impose restrictions in an attempt to control the use of the property. If the property is sold to the highest bidder, the regulations will adversely affect government revenues if they require owners to restrict their pursuit of profitable opportunities. How, then, can it be in the public interest to impose such controls? While some such restrictions have little to recommend them on normative grounds, others can be justified by appeals to efficiency and distributive justice. I discuss four rationales in turn: agency-principal problems that arise from the nature of the contractual situation, avoidance of a "prisoner's dilemma," the entitlement holders' poor information and inability to fend for themselves, and the

65. See generally E. Roberts, The Law and the Preservation of Agricultural Land (1982) (summarizing the development of zoning laws in the United States).

66. Because zoning is a local government function, however, it can itself produce external costs. Large lot zoning in the suburbs combined with selective zoning for industry contributes to the clustering of dirty industry and poor, minority families in central cities or old industrial towns while some suburbs maintain themselves as wealthy enclaves. The wealthy are preserving themselves from the negative externalities of living near the poor, but as a consequence they impose costs on the poor by limiting their locational choices. Neither efficiency nor fairness supports this kind of narrowly focused residential zoning. See Mills, Economic Analysis of Urban Land-Use Controls, in Current Issues in Urban Economics 511 (P. Mieszkowski \& M. Straszheim eds. 1979).

67. For example, the Suffolk County government on Long Island will purchase farmers' "development rights" up to the limit of its budget. The value of these rights is the difference between the value of the property for its highest and best use and its value for agricultural purposes. See E. Roberts, supra note 65, at 76. Less ambitious programs are in effect in Connecticut, Massachusetts, New Hampshire, and New Jersey. Id. at 83-87. 
distribution of scarce benefits to the worthy. Three applications are stressed: federal leasing programs for natural resources, the Homesteading Acts of the nineteenth century, and government transfers to the needy.

1. Contracting Problems: Mineral Leases. - The federal government sells (or gives away) leases that permit private individuals and firms to exploit natural resources on federal lands and on the continental shelf. Most of these leases-e.g., for coal and oil-provide that holders forfeit their claims if they do not actually extract the resource. ${ }^{68}$ A leaseholder who does not wish to exploit the resource, however, can assign or sublease to someone else. ${ }^{69}$ These leases thus are pure property entitlements with coercive use.

Coercive conditions will further efficiency only if they help correct agency-principal problems in the basic lease. Under most federal leases, leaseholders must pay a royalty of $x$ percent on sales proceeds. ${ }^{70}$ Agency-principal problems arise because one hundred dollars' worth of sales is only worth $(1-x)$ dollars to the lessee. Shifting to the lessee the costs, but not all of the marginal gains, leaves the lessee too little incentive to prospect and exploit the resource. The royalty is inefficient ex

68. See Federal Land Policy and Management Act of 1976, § 302, 43 U.S.C. § 1732 (1982); Outer Continental Shelf Lands Act, ch. 345, 67 Stat. 462, § 6(10), 43 U.S.C. $\S 1337$ (b)(2)(B) (1982); Mineral Leasing Act of 1920, ch. 85, 41 Stat. 437, § 7, 30 U.S.C. $\S 207$ (1982); Kalter \& Tyner, Disposal Policy for Energy Resources in the Public Domain, in Energy Supply and Government Policy 51 (R. Kalter \& W. Vogely eds. 1976); Nelson, Undue Diligence: The Mine-It-Or-Lose-It Rule for Federal Coal, 7 Reg. 34 (Jan.-Feb. 1983). Judicial doctrines governing underground coal gasification contain similar holdings. Note, Implied Covenants and the Duty to Develop in Underground Coal Gasification, 59 Tex. L. Rev. 1303 (1981). The Federal Coal Leasing Amendments Act of 1975, Pub. L. No. 94-377, 90 Stat. 1083 (1976) (codified in scattered sections of 30 U.S.C. (1982)), requires development of future coal leases within 10 years, id. $\S 6$, at 1087 (codified at 30 U.S.C. $\$ 207$ (I982)), but does not cover leases issued before 1976 unless the lessees consent. Id. $\S 5(\mathrm{~b})(5)$, at 1086 (codified at 30 U.S.C. $\S 202 \mathrm{a}(5)$ (1982)).

Oil and gas leases are subject to automatic termination for nonpayment of rent unless there is a well on the property capable of producing oil or gas in paying quantities. 30 U.S.C. \& 188(b) (1982). However, the rent is generally set at a minimal fee per acre so that this requirement is not onerous. In practice, leases are seldom terminated for failure to exploit the resource. Council on Economic Priorities, Leased and Lost: A Study of Public and Indian Coal Leasing in the West, 5 Econ. Priorities Rep., No. 2 (1974) [hereinafter cited as Council on Economic Priorities]. Even if one observes no active enforcement, however, the law may still affect both leaseholder behavior and the bid prices for contracts so long as bidders think the provision has some chance of being binding.

69. The sublease must be approved by the Secretary of the Interior. 30 U.S.C. $\S 187$ (1982). At least for oil and gas leases, assignments or subleases can be disapproved "only for lack of qualification of the assignee or sublessee or for lack of sufficient bond." 30 U.S.C. $\$ 187$ a (1982).

70. Low royalties of $8 \%$ to $12.5 \%$ are common. The royalty can be reduced if the lessee demonstrates that lease stipulations make development of a tract uneconomical. Kalter \& Tyner, supra note 68 , at $56-57$. 
post but may be desirable ex ante as a way of sharing the risks of exploitation between the government and the private firm. If such risk sharing is deemed desirable, then a "due diligence" requirement will help correct the inefficiency created by the royalty scheme. ${ }^{71}$

Arguments in favor of restrictive clauses are more difficult to make, however, where the lease is granted in return for a fixed payment. Such provisions are justifiable where market imperfections such as monopoly power or systematically biased information discourage current production. ${ }^{72}$ Absent market imperfections, however, due diligence requirements in such leases encourage excess exploration in the present, controlled only by the government's decision on the quantity of leases to make available each year.

2. "Prisoner's Dilemmas." - It is difficult to be a pioneer in an empty land. Life is easier with neighbors who can help in emergencies, share farm equipment, and assist in capital projects such as construction. Furthermore, as more people settle in a given area, more specialized tradesmen, such as blacksmiths and carpenters, will move in, and villages will be built. Since it is easier to develop one's land once others are nearby, everyone has an incentive to wait for everyone else. Speculators with no interest in farming may purchase some land and hold it for resale. In some markets, speculators can serve a useful economic function, but here they can exacerbate the "prisoner's dilemma."73

71. Private oil and gas leases also frequently contain profit-sharing provisions comhined with clauses requiring the lessee to explore for resources and to exploit them if found. For summaries of the current state of the law in this area, see Comment, The Implied Covenant to Reasonably Develop: Should Hard-Mineral Applications Follow Oil and Gas Precedent?, 20 Hous. L. Rev. 883 (1983); Note, Oil and Gas: Preservation of Leaseholds Following Well Failure, 36 Okla. L. Rev. 151 (1983). For an historical overview, see Swenson, Legal Aspects of Mineral Resources Exploitation, in P. Gates, History of Public Land Law Development 699 (1968).

72. Nelson, supra note 68, at 36-38. The Department of Interior, however, apparently has not enforced these provisions vigorously. Council on Economic Priorities, supra note 68, at 28 .

73. The prisoner's dilemma game between individuals $A$ and $B$ has the following form where $B$ 's net returns are listed first in each box.

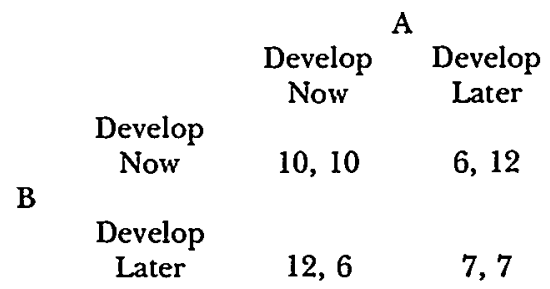

If both develop now, they share the social overhead costs and maximize total benefits. If both wait, they also share costs and lose the profits of early developments. If $A$ develops later while $B$ develops now, $B$ must bear all the startup costs and cannot prevent some of the benefits of this investment from accruing to $A$. Total benefits are less with sequential development either because the early entrant underinvests in social overhead capital or because of scale economies from joint production.

Substituting $(0,0)$ for $(7,7)$ in the above matrix would create a game called "leader." 
Everyone is better off if all settle than if no one settles, but if others settle, then it is best for each person to wait until others have overcome the initial hardships.

One way around the dilemma is to impose a conditionally coercive entitlement rule designed to encourage settlement. The original Homesteading Acts in nineteenth century America, for example, gave people land for a nominal fee after they certified that they had worked the land for five years. ${ }^{74}$ The land could not be sold or given away to private individuals during that period. If a homesteader did not complete his term of resident farming, the land was forfeited to the state. The people attracted to tbe territory by this program both made future economic development easier and aided the political ambitions of the original residents who sought to move their territories toward statehood. Thus, in my terms, the entitlement rule was conditionally coercive, and hence more restrictive than the transferable mineral leases discussed above. ${ }^{75}$

At present, the prisoner's dilemma may well provide an important justification for subsidized housing programs with coercive conditions. Poorly maintained housing affects the value of neighboring property with the net result that no one may find it worthwhile to incur maintenance expenses. If all could be induced to upgrade their property, all would benefit. Subsidies could be provided to landlords and homeowners on the condition that they fix up their property. However, if property owners can sell their upgraded assets to the highest bidder, a subsidy program of this kind is not conditionally coercive. Conditional coercion arises when the government wishes not merely to improve neighborhood quality but also to make it possible for the former residents to remain in the newly upgraded housing. Thus, landlords may be forbidden to evict tenants and tenants may be eligible for subsidy only if they live in apartments that fulfill housing code standards. ${ }^{76}$ Similarly, urban homesteading programs, which are quite self-consciously modeled after the homesteading programs for nineteenth cen-

In this game, each participant would try to be the first to announce that he would develop later in order to induce the other player to develop now.

74. See Act of May 20,1862, ch. 75, 12 Stat. 392; P. Gates, supra note 71, at 393-99.

75. See P. Gates, supra note 71 , at $393-99$. Eventually, the conditionally coercive features of the Homesteading Acts were weakened by the addition of a commutation clause. Homesteaders could purchase their claim outright after a residence of fourteen months. Act of Mar. 3, 1891, cb. 561, \& 6, 26 Stat. 1095, 1098; F. Shannon, The Farmers' Last Frontier, Agriculture, 1860-97, at 51-75, 5 The Economic History of the United States (1945). As a contemporary author pointed out, this clause converted the law into little more than a way of redistributing income to people willing to make a minimal investment in the land. See Hughes, The Abuse of the Homestead Law, 14 Am. Law. 350 (1906). This consequence followed because real estate companies and railroads frequently stood ready to advance the commutation price to the homesteaders in return for a promise to sell the land to the company. Id. at 351.

76. See, e.g., U.S. Housing Act of 1937, § 8, 42 U.S.C. § 1437f(a) (1976). 
tury farmers, encourage low and moderate income people to fix up old housing and impose resale restrictions to ensure that the rehabilitated building continues to provide housing for families with low and moderate incomes. ${ }^{77}$

The prisoner's dilemma rationale is less clearly applicable to natural resource leases, but it may be valid in particular cases. Latecomers may have lower costs than early entrants because those who first develop the resource bear costs that must be shared with later developers. Roads must be built to extract timber from inaccessible areas, and oil exploration by one firm in one area may provide information to owners or leaseholders of neighboring areas. In such situations, due diligence clauses can overcome the incentive to hold back and let others move first.

3. Poor Information and Paternalism. - Following Charles Reich, many commentators view government transfer programs as creating a kind of "new property."78 If so, the new property rights are often conditionally coercive. In general, people cannot sell or give away their benefits to others, and for some benefits, such as public housing, people forfeit their claim to a service by not using it. Even the right to receive straight cash grants through a welfare program with no restrictions on use is not a pure property right. An eligible person can give the payments she receives to anyone but cannot transfer the right to receive these payments. In-kind programs providing such benefits as housing, food, or day care also frequently restrict both the use and transferability of the benefit itself. Such coercion is justified as a way of overcoming the market failure caused by poor information and shopping opportunities, ${ }^{79}$ or from a paternalistic concern for poor children and their families. ${ }^{80}$ Social benefit programs can induce people to consume food, housing, health care, or education by making these services relatively inexpensive and prohibiting transfers.

A similar argument can be used to justify the Homesteading Acts. Those who wished to encourage the development of western lands could well have believed that homesteaders, if left to themselves, would

77. See Department of Housing Preservation and Development, The City of New York, Urban Homesteading, Request for Proposals, Dec. 9, 1983, at 4 (unpublished) (copy on file at the offices of the Columbia Law Review).

78. See Reich, lndividual Rights and Social Welfare: The Emerging Legal 1ssues, 74 Yale L.J. 1245 (1965); Reich, The New Property, 73 Yale L.J. 733 (1964).

79. Barlow v. Collins, 397 U.S. 159 (1970), illustrates a situation in which program beneficiaries themselves argued for restrictions on the transferability of their entitlements. Petitioners were tenant farmers eligible for payments under the upland cotton programs. The law permitted them to assign their payments only "to finance making a crop." Id. at 160 . In 1966 the definition of this phrase was changed to permit tenants to use advances to pay land rent. Tenants argued that this apparent increase in flexibility actually reduced their benefits under the program because landlords were now able to insist on assignments as a condition for obtaining a lease to work the land. Id. at 163.

80. See generally Rose-Ackerman, Social Services and the Market, 83 Colum. L. Rev. 1405 (1983) (discussing the rationales for in-kind programs). 
have had an inefficiently short time horizon. Conditional coercion encouraged homesteaders to endure the hard initial years by subsidizing fixed costs in a way that gave them an incentive to remain on the land. Eventually, their skills improved, and the risks of farming fell. Here, too, the efficiency rationale based on imperfect information merges into a kind of paternalism.

4. Distribution to the "Worthy." - Suppose that for some reason the free market allocation of a scarce public benefit is unacceptable. Assume further that the number of qualified individuals using some clear standard such as income, employment status, or family composition exceeds the supply available. Thus, program administrators face a distributive problem that may be solved in a number of ways, including first-come-first-serve queues, the approval of applications, under-thetable payoffs, or a lottery. Alternatively, restrictions may be imposed that are less onerous for those who most deserve to receive the benefit. If determining worthiness through tests and application approval is costly and unreliable, the restrictions are a substitute sorting device. Such requirements may be particularly desirable if they also serve a productive purpose, as did the rural and urban homesteading laws.

Consider first the Homesteading Acts. Central to the homesteading program was the idea that a newly available resource (e.g., western land suitable for farming) should not go to those who already had capital but to those without other wealth. 81 This, however, was only an argument for giving the land to the poor in the first instance, not for requiring them to work on the property. To justify coercive conditions and restrictions on transfer we must add a second factor: in practice, the number of valuable sites was less than the number of landless people so long as the state took into account both the scale economies of production and the transaction costs of assembling a farm from a multitude of small entitlements. Thus, there needed to be some method to assign sites other than willingness. to pay since market sales could defeat the redistributive purpose. In this context, homesteading emerges as a plausible choice. It is a more efficient allocation mechanism than a first-come-first-served queue since the time expended is not wasted waiting in line but is used in productive activities. Seen in this light, a conditionally coercive rule can use willingness to work to determine

81. See, e.g., Seymour v. Sanders, 21 F. Cas. 1133, 1135 (C.C.D. Minn. 1874) (No. 12,690 ) ("A leading object of the enactment was to benefit the poor man who was unable to buy the lands at government prices and receive his title at once and without conditions."), reprinted in J. Lewis, Leading Cases on the Public Land Laws of the United States 219 (1879). Nonetheless, homesteading accounted for, at most, "less than a sixth of the new homes and a little over a sixth of the acreage" in the United States between 1860 and 1900 . F. Shannon, supra note 74, at 51 . Gates refers to the mixture of sales and homesteading in the western states as an "incongruous land system." $P$. Gates, supra note 71, at 435. Although Shannon argues that the Acts had little redistributive impact, Gates points out the Act's role in limiting absentee ownership of large tracts. 
who among the poor can best develop the resource. Of course, this policy also means that the very poor with no farming skills do not benefit from the program. It represents a compromise between accomplishing redistributive goals and assuring the efficient development of resources.

A similar rationale underlies many social welfare programs. When the number of needy people exceeds the supply of subsidized goods, it seems prudent to ration the scarce supply only to those people who will actually use the in-kind benefit themselves. Selling subsidized apartments to the highest bidders would undermine the redistributive purposes of the program. Since the price is not set to clear the market, demand will exceed supply even when transferability is restricted. Therefore, costly conditions may be added, such as willingness to perform maintenance chores in the building or to spend time fixing up the premises. The analogy to the Homesteading Acts is particularly close for redistributive programs that also have economic development or growth as a secondary goal. The restrictions on use and transferability in these programs can both accomplish redistributive objectives when demand exceeds supply at the subsidized price and encourage neighborhood preservation in much the same way as the Homesteading Acts induced people to endure the hardships of farming on the frontier.

Once again, however, this mix of efficiency and distributive rationales cannot be extended indefinitely. For example, it cannot be used to justify the coercive conditions in federal mineral leasing programs. Most leases are sold to high bidders, not given to those deemed especially worthy independent of their willingness to pay. Noncompetitive leases that are given to the "first" qualified applicant have distributive consequences, but not ones that make sense on normative grounds. ${ }^{82}$ Furthermore, given the specialized skills needed to exploit mineral resources, it seems unlikely that these programs should be designed to serve a redistributive purpose:

\section{INALIENABILITY AND CitizENSHIP}

The analysis of inalienability helps to illuminate a theme that has preoccupied students of capitalist democracy: How insulated should the state be from market pressures?83 This Part discusses one aspect of the broader problem: When should rights be transferable and when

82. 26 U.S.C. $\$ 226$ (c) (1982); 43 C.F.R. $\$ \$ 3111.1-.7$ (1984). Council on Economic Priorities, supra note 68 , at 22-23, describes the allocation of coal leases prior to the 1976 law. Of 242 lease offerings during the period 1921-1973, 10\% drew no formal bidders and so were awarded at low rates to the original applicant for the sale. In $59 \%$ of the competitive sales only two bidders participated. The average bid was $\$ 3.31$ per acre. The Council on Economic Priorities claimed that the prices paid, even when rent and royalty payments are considered, were far below the discounted present value of the mineral resources. Id. at 27-28.

83. See, e.g., G. Brennan \& J. Buchanan, The Power to Tax: Analytical Founda- 
must they be exercised by all who possess them? Should people be able to contract out of duties, and should duties be imposed even if the required services could be purchased in a market? My aim here is not to provide a comprehensive answer to these questions. Instead, it is to show how any answer requires us to confront the complexity of the idea of citizenship. To make the analysis concrete, I will show how alternative conceptions of citizenship have different implications for voting, military service, and jury selection. The analysis concentrates on the difference between rights and duties and between alienability and inalienablity.

\section{A. Alienable and Inalienable Rights}

Under the weakest conception of citizen responsibility, citizenship services are obtained under a regime of alienable property rights. Votes can be sold, given away, or left unused. Both soldiers and jurors are obtained in the regular labor market by offering compensation to people willing to participate. Qualifications may be imposed on both soldiers and jurors to assure a supply of good soldiers and qualified fact finders, but within these groups, market forces operate. This system minimizes the difference between the government and the economy. The impact of economic pressures can be attenuated, however, by moving to a system of inalienable rights.

1. Votes. - When voting is an alienable right, everyone meeting statutory requirements of age and citizenship would be entitled to one free voting right from the government, but people could then sell or give their votes to others. The affirmative case for alienability is derived from research on voting behavior which reveals that many voters are poorly informed and apathetic. ${ }^{84}$ Similar conditions, after all, apply to voting rights in corporations. Although owners may not sell their proxies, ${ }^{85}$ they may give their votes to management or to anyone else

tions of a Fiscal Constitution (1980); C. Lindblom, Politics and Markets (1977); S. RoseAckerman, Corruption: A Study in Political Economy (1978).

84. See W. Miller, A. Miller \& E. Schneider, American National Election Studies Data Sourcebook 1952-1978 (1980) [hereinafter cited as Data Sourcebook].

85. Of course proxies can be sold if the shares of stock to which they are attached are sold as well. Manne, Some Theoretical Aspects of Share Voting, 64 Colum. L. Rev. 1427 (1964). Robert Clark has argued that sales of votes should be permitted, especially in fights for corporate control. See Clark, Vote Buying and Corporate Law, 29 Case W. Res. L. Rev. 776, 790-801 (1979). Frank Easterbrook and Daniel Fischel contend that this argument neglects the agency costs of separating voting from ownership. Easterbrook \& Fischel, Voting in Corporate Law, 26 J.L. \& Econ. 395, 410-11 (1983).

While the sale of proxies is illegal under New York law, N.Y. Bus. Corp. Law $\$ 609$ (e) (McKinney 1963), no federal statute forbids such conduct. See Clark, supra, at 777 n.9. Furthermore, gifts of proxies can generally be revoked at will. $5 \mathrm{~W}$. Fletcher \& O. Smith, Fletcher Cyclopedia of the Law of Private Corporations $\$ 2062$, at 256 (rev. perm. ed. 1976). Proxies can be irrevocably transferred to others if coupled "with an interest." Id. A creditor, for example, may demand the right to vote some portion of a company's stock in return for extending funds. Id. at 20-21 (Cum. Supp. 1984). Since 
who offers to act as the shareholders' proxies. ${ }^{86}$ Scholars have justified this delegation of voting power on the ground that stockholders have little incentive to become well informed about firms' policies. ${ }^{87}$ What is wrong, then, with extending this analogy to the state?

1 do not want to go so far as to advocate vote selling in political life. Vote selling is widely recognized to be inconsistent with egalitarian, democratic principles because it biases political decisions in favor of the wealthy .88 However, in a direct democracy in which choices are made by unanimous consent, the buying of votes does assure choices that benefit all citizens given the existing distribution of resources. ${ }^{89}$ This can only be a desirable outcome, however, if the existing distribution is believed to be fair. ${ }^{90}$ And even this limited defense of vote selling does not survive the move to a representative system making choices by majority rule. ${ }^{91}$

The current prohibition against donations cannot, however, be so easily dismissed. Since voters who pull party levers or follow the endorsements of The New York Times are de facto donating their votes, why not permit more formal assignments which, like corporate proxies, can be revoked at any time before the election? In spite of a generally held belief that people should use their own independent judgment in deciding how to vote, we do not impose any tests on the electorate to determine their level of knowledge of candidates and issues. We are torn, then, between two alternative views of democracy. Even when alienability through the market is outlawed, this conflict within democractic theory remains. On the one hand, there is the belief that voting is an individual, private act that should not be examined too closely by the state. On the other hand, the value of a representative democracy depends upon citizens making responsible, well-informed choices. This conflict is illuminated, but not resolved, by trying to determine whether voting rights should be governed by a modified inalienablity rule.

this scheme approximates the sale of a proxy, it has caused some confusion in the courts, id. $\S 2052$, at 209 n.5, and is apparently a rather uncommon method of creditor control.

86. Because of the possibilities for abuse by management, the SEC regulates proxy solicitations. Regulations promulgated under the Securities and Exchange Act of 1934 prohibit fraud, permit shareholders to solicit proxies and to include certain of their proposals in the proxy statement, and require disclosure from opposition groups in proxy contests. See 17 C.F.R. $§ 240.14$ a (1984). State regulation of proxy solicitations, however, is practically nonexistent. See Eisenberg, Access to the Corporate Proxy Machinery, 83 Harv. L. Rev. 1489 (1970).

87. See, e.g., Clark, supra note 85 , at $779-84$.

88. For example, even staunch defenders of the market accept this argument. See J. Buchanan \& G. Tullock, The Calculus of Consent 270-76 (1962).

89. 1d. at 276-77.

90. For a recent critique of Buchanan's position in favor of the status quo distribution, see Rose-Ackerman, A New Political Economy?, 80 Mich. L. Rev. 872 (1982).

91. J. Buchanan \& G. Tullock, supra note 88 , at $270-76$. 
2. Soldiers and Jurors. - Despite the consensus against the sale of votes, there is no widely held belief that government should be isolated from economic forces. Public agencies commonly pay market prices for capital and other inputs. More controversially, the military's entrance into the labor market to obtain soldiers reflects current American practice and has been widely advocated by economic analysts. ${ }^{92}$ An all-volunteer military requires the government to take into account the opportunity cost of personnel. ${ }^{93}$ The armed services decide what sort of people they wish to recruit, but the people who actually decide to serve are those who believe that military service, given existing pay and benefit levels, is at least as good as their best private sector option. Unlike a draft with a fixed pay scale, the volunteer army makes taxpayers pay the social costs of military personnel, ${ }^{94}$ shifting this citizenship responsiblity from the young to the general public.

Some commentators, however, object to this shift of responsibility on citizenship grounds. They claim that choosing soldiers who prefer military service to their opportunities in civilian life is undesirable in a democracy. Two kinds of people can be expected to volunteer: those with relatively low paying, unattractive job prospects in the private sector and those who like fighting and prefer military service over civilian jobs that pay as well or better. The army's personnel budget reflects the opportunity cost of recruits on the margin, but such an army may have long-term consequences for the stability of the society. The country may be overly likely to engage in militaristic adventures if its soldiers are people who like fighting more than the rest of us. ${ }^{95}$ Alternatively, the potential for violent confrontations between rich and poor may be increased if the armed forces are composed of unskilled people who learn little beyond the use of weapons during their years in

92. See, e.g., Amacher, Miller, Pauly, Tollison \& Willett, The Economics of the Military Draft, in The Military Draft 347 (M. Anderson ed. 1982) [hereinafter cited as Amacher, Military Draft].

93. Id. at $366-75$.

94. Of course, so long as wages are set to attract enough recruits and so long as some people would have volunteered at lower pay levels, some soldiers are earning a surplus over their opportunity wages, and payrolls overstate the economic cost of a volunteer army.

95. See Janovitz, The Logic of National Service, in The Military Draft 403, 431 (M. Anderson ed. 1982) ("If the armed services-through some sort of nationwide draftare continuously faced with the task of absorbing recruits to whom the military way of life is basically uncongenial, or even repellent, there is a useful check on the development of a highly differentiated counter-civilian ethos."). Similarly, McNeill criticizes a draft that exempts college students. He argues that "the existing policy of exempting the future leaders of civilian life from military service positively invites divergence of viewpoint and seems almost suicidal in a democracy. . . . [1]t is precisely those who go to college and are headed for the privileged places in our society who should be drafted." McNeill, The Draft in the Light of History, in The Military Draft 59, 64-65 (M. Anderson ed. 1982). 
uniform..$^{96}$

Analysts have seldom viewed jury duty, unlike military service, as a job like any other that should be made available to qualified applicants. Yet it is difficult to see why a sharp distinction should be made between soldiers and jurors. Using the market to obtain jurors would make the public at large rather than randomly selected individuals bear the cost of jury service ${ }^{97}$ and is consistent with an economic analysis that emphasizes the possible trade-off between the opportunity cost of jurors' time and their factfinding ability. ${ }^{98}$ The objections, however, parallel those made for the draft. First, jury duty is seen by many as a duty of citizenship that people should not be able to opt out of because of better private opportunities elsewhere. Second, the process itself might be undermined if juries were staffed entirely by volunteers. Within demographic categories, the jury would be unrepresentative because those with high opportunity wages would not serve. This bias might destroy the jury's representative character. ${ }^{99}$

For military and jury service, using the market would imply that these activities are rights rather than duties. However, unlike voting, the distinction between inalienability and alienability is not central. People have a right to serve if the government finds them qualified, and no one will serve who does not find the terms of employment desirable. Like most private employment relationships, however, these jobs cannot be sold by the incumbent. As we shall see below, the distinction between alienability and inalienability only becomes salient when these activities are duties assigned by the state.

96. See Amacher, Military Draft, supra note 92, at 377-78 (examining the argument that a volunteer army will be disproportionately composed of blacks and members of other disadvantaged minority groups).

97. At present, pay is far below opportunity costs for most people. In New York State, jurors are paid not more than $\$ 12$ per day plus food and travel expenses and $\$ 1.50$ for each evening session. Extra compensation is permitted for trials lasting more than 30 days. Furthermore, although employers cannot discharge or penalize employees for serving on juries, they need not pay them for days missed. N.Y. Jud. Law \$\$ 519 , 521 (McKinney Supp. 1984).

98. Klevorick, Jury Composition: An Economic Approach, in The Interaction of Economics and the Law 81-99 (B. Siegan ed. 1977).

99. This argument, of course, assumes that representativeness is desirable. The case for this position is made in two very different ways. On one hand, G. Calabresi \& $\mathrm{P}$. Bobbitt, supra note 37, at 57-64, argue that juries can be used to make tragic choices that strain the fabric of society. On the other hand, some observers believe that a representative jury will produce more accurate decisions, especially when "reasonableness" or "community standards" are at issue. See, e.g., Weiner, The Civil Jury Trial and the Law-Fact Distinction, 54 Calif. L. Rev. 1867, 1876-94 (1966). For evidence on juror behavior, see H. Kalven, Jr. \& H. Zeisel, The American Jury (1966); Severance \& Loftus, Improving the Ability of Jurors to Comprehend and Apply Criminal Jury Instructions, 17 L. \& Soc'y Rev. 153 (1982). 


\section{B. Inalienable and Alienable Duties}

Under the strong concept of inalienable duties, the state requires certain actions of some or all citizens and forbids the transfer of these duties to others. Every eligible citizen must vote; the military uses a draft or has a universal service requirement; and jury duty is an obligation of those called to serve. The coercive nature of the duties of citizenship can be reduced by making them alienable. Thus, for example, persons drafted into the armed forces could be permitted either to purchase substitutes or locate others willing to take their places.

1. Votes. - Consider voting first. In some democratic countries, such as Australia, voting is not only inalienable but also required. The law is enforced by imposing a fine on those who fail to come to the polling place. ${ }^{100}$ Thus, in practice, the state has set a price for not voting. People with a very high opportunity cost of time may decide not to go to the polls. A relatively low fine, however, should be sufficient to assure a large turnout.

What can be said for such coercion in the name of citizenship? One argument is based on the free rider problems that arise in politics. Although the cost of voting is usually small, the chance of being decisive, even in a small town, is almost nonexistent. ${ }^{101}$ When the law does not require voting, as in the United States, turnout is far less than one hundred percent even in important national elections ${ }^{102}$ and may well be under twenty-five percent for relatively unimportant offices or in elections with little at stake. So long as indifference can be recorded, making voting an inalienable duty assures that all eligible citizens' preferences are taken into account and might seem to produce a more legitimate democratic result. ${ }^{103}$ However, if many people are lazy or bored by politics, and have only vague preferences, they may not bother to vote without coercion and if coerced might well vote randomly or on the basis of whim and prejudice. Even permitting voters to register their indifference would not solve this problem since the truly apathetic might still vote randomly. They would have no more incentive to record their apathy than to cast a ballot for one of the candidates. The problem for them is not that they realize that one vote is unlikely to affect the outcome, but that they simply do not care which candidate is chosen. Therefore, avoiding coercion may be a better way to preserve democratic values than making voting an inalienable duty. When voting is an inalienable right whose exercise is slightly costly because of the time and trouble of going to the polls, the people who do cast ballots must feel that they have an obligation to do so in spite of their lack

100. See H. Emy, The Politics of Australian Democracy: Fundamentals in Dispute 596-97 (2d ed. 1978).

101. See B. Barry, Sociologists, Economists and Democracy 13-23 (1970).

102. See Data Sourcebook, supra note 84, at 303-28.

103. See Miller, A Program for Direct and Proxy Voting in the Legislative Process, 7 Pub. Choice 107 (1969). 
of marginal impact. ${ }^{104}$ As a consequence, they will be more likely to find out about the candidates than the citizenry as a whole. ${ }^{105}$

The alternative of treating voting as an alienable duty does not have much to recommend it. 1t would permit the apathetic and the undecided to delegate their choices to someone else by sale or gift. It has all the problems outlined above for alienable rights, exaggerated by the fact that votes either must be used or transferred. Under both inalienable rights and alienable duties, less than one hundred percent of the eligible voters cast ballots, but the former policy limits the influence of the politically aware to their own vote and does not give those who are wealthy an undue advantage. Of course, as any student of politics knows, making voting an inalienable right does not eliminate the impact of wealth on electoral outcomes, but it seems to be a minimal condition.

2. Soldiers and Jurors. - The arguments for forced jury duty and military service are somewhat different. Unlike voting, all qualified people are not called upon to serve at a single point in time. Therefore, the state must decide who should serve. If military service and jury duty are seen as duties of citizenship, rather than jobs much like any other, a draft based on a lottery with no buyout possibilities seems to impose that duty most fairly. However, it is clearly more costly for society as a whole since some people with high opportunity wages in the private sector or little aptitude for soldiering or fact finding will be called. This cost will be borne either by the draftee, if wages are not tied to opportunity costs, or by the taxpayers, if they are. The country's labor resources are being used inefficiently, but in a way that treats the risks of military service and the inconvenience of jury duty as duties of citizenship that every qualified person must be willing to accept.

Suppose, however, that these duties are imposed fairly but are made alienable. In other words, people are assigned duties by the state but can induce others to perform them either for a fee or from altruistic motives. Thus, people are drafted or called to jury duty but may purchase substitutes or try to induce their friends or relatives to serve in their place. Such a system of alienable duties appears to have little to recommend it. Instead of striking a balance between competing values, it reduces both the fairness and the efficiency of the system.

To see this, consider a situation in which military service was an alienable duty. During the United States Civil War a compromise was sought between the inefficiency of a draft and its appeal as a fair way of imposing a duty of citizenship. In both the North and the South draftees could either buy their way out or buy a substitute. ${ }^{106}$ The system

104. Benn, The Problematic Rationality of Political Participation, in Philosophy, Politics and Society (P. Laslett \& J. Fishkin eds. 1979).

105. See Shubik, On Homo Politicus and the Instant Referendum, 9 Pub. Choice 79 (1970).

106. See E. Murdock, Patriotism Limited: 1862-1865: The Civil War Draft and the 
amounted to a volunteer army financed by wealthy draftees instead of taxpayers as a whole. While soldiers may have ended up being paid the opportunity cost of enlistment, the government in planning its military activity was not required to take these opportunity costs into account. Therefore, it had an incentive to use too much manpower. Most criticism, however, attacked the unfairness of the system that (like the volunteer army today) permitted the wealthy to avoid service. In fact, the system quickly broke down in the North as localities and states first passed laws appropriating money to enable everyone to buy his way out and then began to pay bounties to enlistees. ${ }^{107}$ In the South the purchase of substitutes was heavily criticized and was abolished soon after it was begun. ${ }^{108}$

If we rule out the option of alienable duties, then we are left with a choice between a market-based system under which military and jury service are rights that are voluntarily accepted, and a system of inalienable duties. Each alternative has something to recommend it, and a mixed strategy may be desirable. Thus, a volunteer army could be advisable in peacetime when military jobs are no more dangerous than many other forms of employment, but might be replaced by a draft based on a lottery in wartime. Jurors in cases requiring expert knowledge and the commitment of substantial time and energy might be chosen by paying qualified volunteers a high enough wage to clear the market. In situations in which a cross section of the population is required, jury service could be made an inalienable duty with pay levels set approximately equal to the average wage.

\section{Conclusions}

The classification of entitlements developed here encompasses a broad range of property relations and analyzes rationales that incorporate and go beyond exclusively economic arguments. The economic rationales themselves are wide ranging and include problems of imperfect information and foresight, as well as administrative costs and exteralities. Nonetheless, I have also attempted to incorporate distributive arguments and to point out how alternative conceptions of citizenship affect the analysis of entitlement rules. My aim is not to justify all existing restrictions, but to isolate plausible rationales for some.

We have seen how restrictions on the transferability, ownership,

Bounty System (1967); J. Randall, Constitutional Problems Under Lincoln (rev. ed. 1963). For a relatively favorable view of this practice, see Wittman, supra note 19 , at 78 .

107. E. Murdock, supra note 106; J. Randall, supra note 106.

108. A. Moore, Conscription and Conflict in the Confederacy (1924). According to Moore, substitution was originally supported in the South as a way "to reserve skill and talent for service in essential industries." Id. at 27. Criticism mounted when it was found that many who sought substitutes were not only wealthy but became war profiteers. Id. at $27-29$. The market price of a substitute increased from $\$ 1500$ to $\$ 6000$ near the end of 1863 . Id. at $29-30$. 
and use of property can be justified under a range of different assumptions about the strncture of the world and the cost of alternatives. I have also tried to show the limited applicability of some kinds of inalienability rules. Easy generalizations are frequently invalid. While an argument can be made for relying on blood donations, it cannot be generalized to products like used cars, even though they share similar informational characteristics. Shareholders, but not citizens, can give away their votes. Federal homesteading laws and federal mineral leases may appear similar in form but have very different rationales. The sale of both blood and "old" eagles might be permitted if certain institutional arrangements are not too costly to establish.

Inalienability is frequently justified not as an ideal policy but as a second-best response to the messiness and complexity of the world. It is generally possible to conceive of an alternative policy that would be superior if transaction costs were lower. The major exception involves the ideal of citizenship, where insulation from market forces may be desirable in principle and the main issue is whether to rely on voluntary donations or on coercion to achieve public goals. Thus, even in a firstbest world without transaction costs, few people would advocate selling political votes. In contrast, if the argument against the sale of blood rests primarily on quality control grounds, a cheap and effective test for contamination would undermine the argument. This reliance on imperfect information and transaction costs to justify inalienability rules should not be seen as a weakness of the analysis, however. Instead, it is a way to rescue the concept of inalienability from its simplistic rejection by market-oriented economists or its overly enthusiastic embrace by paternalistic moralists. 